\title{
U-Pb zircon dating of Early Paleozoic gabbro from the Nantinghe ophiolite in the Changning-Menglian suture zone and its geological implication
}

\author{
WANG BaoDi*, WANG LiQuan, PAN GuiTang, YIN FuGuang, WANG DongBing \& \\ TANG Yuan
}

Chengdu Institute of Geology and Mineral Resources, Chengdu 610081, China

Received June 28, 2012; accepted August 28, 2012; published online October 18, 2012

\begin{abstract}
The Nantinghe ophiolite is located in the northern part of the Changning-Menglian suture zone in southeast Tibet. It is composed of meta-peridotite, cumulative gabbro, meta-gabbro, plagioclase amphibolite and meta-basalt. Zircon U-Pb dating of the cumulative gabbro gives concordant ages of 473.0 $\pm 3.8 \mathrm{Ma}$ and 443.6 $\pm 4.0 \mathrm{Ma}$ respectively, indicating the early and late episodes of mafic magmatisms during the Paleo-Tethys oceanic rifting. The 16 LA-ICPMS zircon U-Pb analyses of meta-gabbro yield a weight mean age of $439 \pm 2.4 \mathrm{Ma}$. The gabbro shows relatively low contents of $\mathrm{SiO}_{2}(46.46 \%-52.11 \%), \mathrm{TiO}_{2}(0.96 \%-1.14 \%)$ and $\mathrm{K}_{2} \mathrm{O}$ $(0.48 \%-0.75 \%)$. Its trace element distribution patterns are partly similar to those of the mid-ocean ridge basalts, and part is depleted in high field strength elements such as $\mathrm{Nb}, \mathrm{Ta}, \mathrm{Zr}$, Hf and Ti. These features suggest that the mafic rocks were probably formed in a MORB-like or backarc rift basin setting. The zircon U-Pb age of gabbro is consistent with a late crystallization age of the cumulative gabbro from the Nantinghe ophiolite, suggesting that the Paleo-Tethys oceanic basin was opened during 444-439 $\mathrm{Ma}$, possibly as a backarc basin. It is the first precise age which defines the formation time of the early Paleozoic ophiolite in the Changning-Menglian suture zone. These geochronological and geochemical characteristics of the Nantinghe ophiolite are consistent with those from the Guoganjianianshan and Taoxinghu of the Longmu Co-Shuanghu suture in the Qiangtang region. Thus, we suggest that the both Changning-Menglian and Longmu Co-Shuanghu sutures were probably transformed from the relic oceanic crust of the uniform Paleo-Tethys, which likely represents the original and main Paleo-Tethys oceanic basin.
\end{abstract}

Changning-Menglian suture zone, Longmu Co-Shuanghu suture zone, Nantinghe, Early Paleozoic, cumulative gabbro

Citation: Wang B D, Wang L Q, Pan G T, et al. U-Pb zircon dating of Early Paleozoic gabbro from the Nantinghe ophiolite in the Changning-Menglian suture zone and its geological implication. Chin Sci Bull, 2013, 58: 920-930, doi: 10.1007/s11434-012-5481-8

The timing of the formation of the Changning-Menglian suture zone, which belongs to the Tethys tectonic domain, has a great significance for the Tethys ocean evolution and paleogeographic reconstruction. It is generally believed that the Sanjiang area is represented as an archipelago ocean, which is composed of some terranes and oceanic basins during the Paleo-Tethys stage, and the Changning-Menglian suture zone was represented as the main branch of the ocean [1-6]. However, the opening time of the ocean basin, represented by the Changning-Menglian suture zone, is still

*Corresponding author (email: baodiwang@163.com) debated. Some suggested that the Changning-Menglian ocean basin formed during Early Carboniferous, based on the oceanic island-type and MORB-type basalts from the Pingzhang Formation of the Lower Carboniferous [7]. However, according to the isotopes of volcanic rocks from the Tongchangjie, some proposed that it formed during Devonian [3,8]. Yang et al. [9] also thought that it formed at Devonian, based on the associated Late Devonian radiolarians and conodonts in the siliceous and siliceous mudstone with the pillow basalts in the Changning-Menglian suture zone from the Gengma area of the western Yunnan. So far, lacking of the high-precise geochronology of the Changning- 
Menglian suture zone, limits the study on the evolution of the Tethys ocean.

\section{Geological background and petrology}

The Changning-Menglian suture zone extends from Changning and Tongchangjie of Yunxian in the north, through Shuangjiang and Laochang of Lancang, and to Myanmar in the south, which contains many complete ophiolitic mélanges. The Baoshan block, consisting of Paleozoic platform shallow sea shelf carbonate deposition and sandy or muddy sediments, lies to the west of the Changning-Menglian suture zone, and Lancang-Menghai island arc belt lies to the

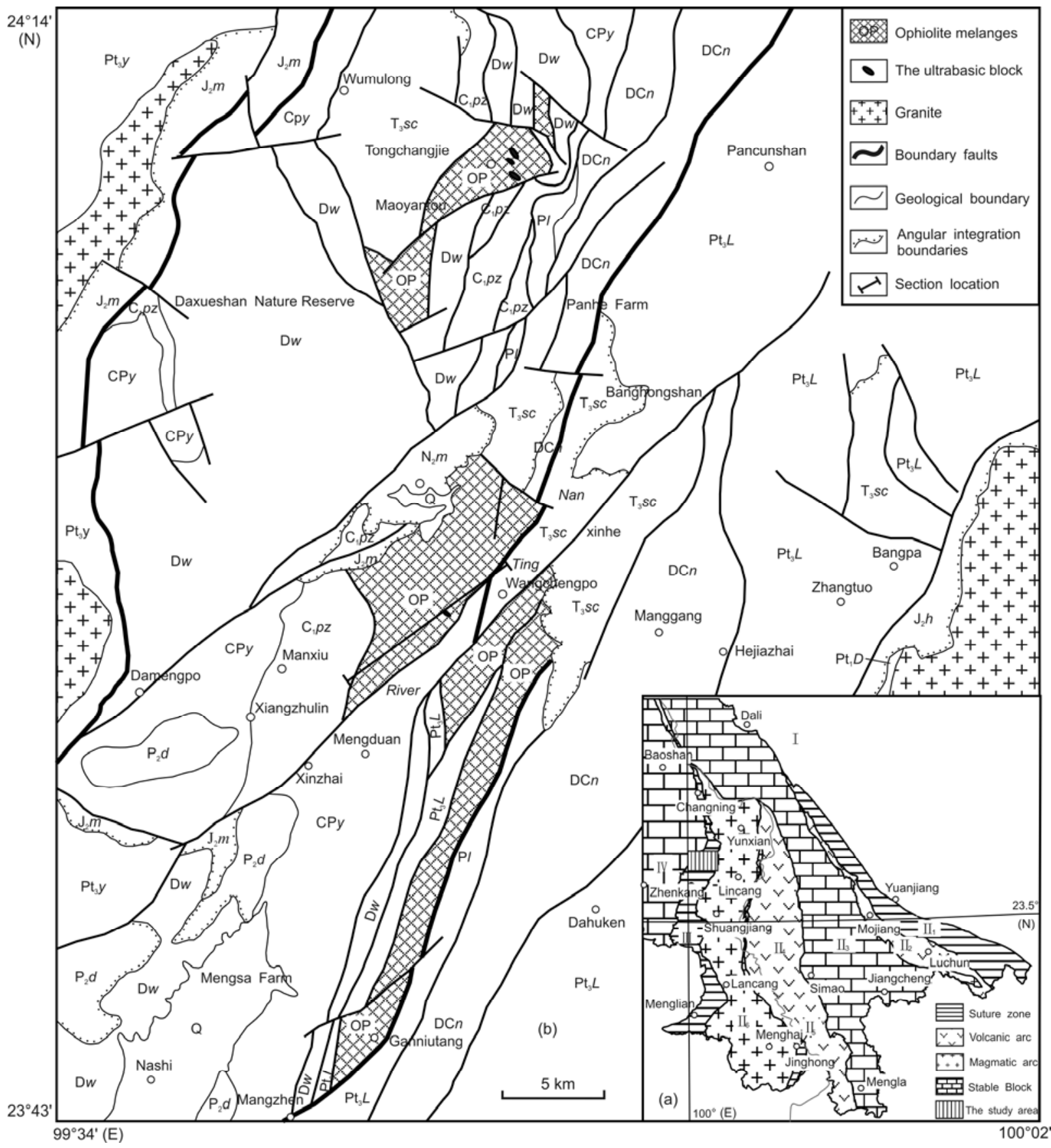

Figure 1 Tectonic sketch map of Sangjiang area in southwest China (a) and simplified geological map in the Nantinghe area (b). Q, Quaternary (Not classified); $\mathrm{N}_{2} m$, Mangbang Formation; $\mathrm{N}_{1} s h$, Sanhaogou Formation; $\mathrm{J}_{2} m$, Mengga Formation; $\mathrm{T}_{3} s c$, Sanchahe Formation; $\mathrm{Pl}$, Laba Formation; $\mathrm{P}_{2} d$, Damingshan Formation; $\mathrm{CP} y$, Yuntangzhai Formation; $\mathrm{C}_{1} p z$, Pingzhang Formation; Dw, Wenquan Formation; DCn, Nanduan Formation; Pt $3 y$, Yungou Rocks Group; $\mathrm{Pt}_{3} L$, Lanchang Rocks Group; $\mathrm{Pt}_{1} D$, Damenglong Rocks Group. I, Yangtze Block; $\mathrm{II}_{1}$, Ailaoshan suture zone; $\mathrm{II}_{2}$, Mojiang-Luchun volcanic arc; $\mathrm{II}_{3}$, Lanping-Puer Block; $\mathrm{II}_{4}$, Yunxian-Jinghong volcanic arc; $\mathrm{II}_{5}$, South lancangjiang suture zone; $\mathrm{II}_{6}$, Lincang-Menghai magmatic arc; III, Changning-Menglian suture zone; IV, Baoshan-Zhenkang Block. 
east of it (Figure 1(a)). The Nantinghe ophiolites occur in the Bankong-Nantinghe-Tongchangiie area, intermittently extending about $80 \mathrm{~km}$ in length and $0.5-3 \mathrm{~km}$ in width in the study area. The Nangtinghe ophiolites tectonically emplaced into the Late Paleozoic strata, which is composed of the Wenquan Formation (Dw), the Nanduan Formation (DCn), the Pingzhang Formation $\left(\mathrm{C}_{1} p z\right)$, the Yuntangzhai Formation (CPy) and the Damingshan Formation $\left(\mathrm{P}_{2} d\right)$ [10]. Both of the Devonian Wenquan Formation $\left(\mathrm{D}_{w}\right)$ and the Devonian-Carboniferous Nanduan Formation (DCn) are the accumulation of bathyal-abyssal silicon-mud flysch and volcanic formation in the expanding oceanic basin of Changning-Menglian. The Lower Carboniferous Pingzhang Formation $\left(\mathrm{C}_{1} p z\right)$ is composed of intermediate-basic volcanic rocks, volcanic breccia, limestone and clastic rocks. The Carbonifeours-Permian Yuntangzhai Formation (CPy) and the middle Permian Damingshan Formation $\left(\mathrm{P}_{2} d\right)$ consist of oolitic and biological clastic limestone, which are island arc or intra-oceanic arc volcanic sedimentary formation in the spreading process of the oceanic basin (Figure 1(b)) [10]. The fragments of the Nantinghe ophiolite mainly consist of amphibolites, actinolitites, schists, serpentinization olivine- pyroxenites, cumulative gabbros, meta-gabbros and meta- basalts. The ultramafic rocks commonly display the layered, layered-like, cystic and granular pattern. The incomplete reconstructed ophiolite consists of metamorphic peridotites, cumulus complexs, meta-gabbros and lavas (Figure 2), and each of them contact by a fault.

The homogeneous gabbros $\left(23^{\circ} 59^{\prime} 04.0^{\prime \prime} \mathrm{N}\right.$; $\left.99^{\circ} 42^{\prime} 38.6^{\prime \prime} \mathrm{E}\right)$ and cumulative gabbros $\left(23^{\circ} 59^{\prime} 22.3^{\prime \prime} \mathrm{N}, 99^{\circ} 43^{\prime} 26.3^{\prime \prime} \mathrm{E}\right)$ do not directly contact. The former displays directional structure, medium-fine grain gabbroic texture, accompanying with fresh residual pyroxene, universal second-rate hornblende, and epidotization and prehnitization of plagioclase. The cumulative gabbros obviously display the interval dark and light colors layered structure, reflecting typical magma crystallization differentiation and accumulation (Figure $3(a))$. The dark layers mainly consist of pyroxene and hornblende, and light layers primarily contain the plagioclase and a few of quartz. The cumulative gabbros show medium-fine grained texture $(0.5-2.0 \mathrm{~mm}$ in size), which mainly contain plagioclase $(30 \%-45 \%)$, tremolite-actinolite (15\%$20 \%)$, epidote $(15 \%-20 \%)$, quartz $(3 \%-5 \%)$ and carbonate (3\%-5\%) (Figure 3(b)). Plagioclase is oligoclase. The long columnar tremolite and actinolite occur in the epidote aggregate. The relicts and pseudomorph of pyroxenes, the xenomorphic granular and irregular aggregates of epidote, the fine grain quartz are unevenly distributed in the cumulative gabbros.

\section{Analytical methods}

Zircons were separated using conventional heavy liquid and magnetic separation techniques in Hebei institute of regional geological survey. Cathodoluminescence (CL) images were obtained for zircons prior to analysis, using scanning electron microscope of FEI Quanta 400 FEG at the State key laboratory of continental dynamics, Northwest University, in order to characterize internal structures and choose potential target sites for U-Pb dating. LA-ICPMS zircon $\mathrm{U}-\mathrm{Pb}$ analyses were conducted on an Agilent 7500 ICP-MS equipped with a GeoLas 2005 laser, housed at the National Key Laboratory of Geological Processes and Mineral

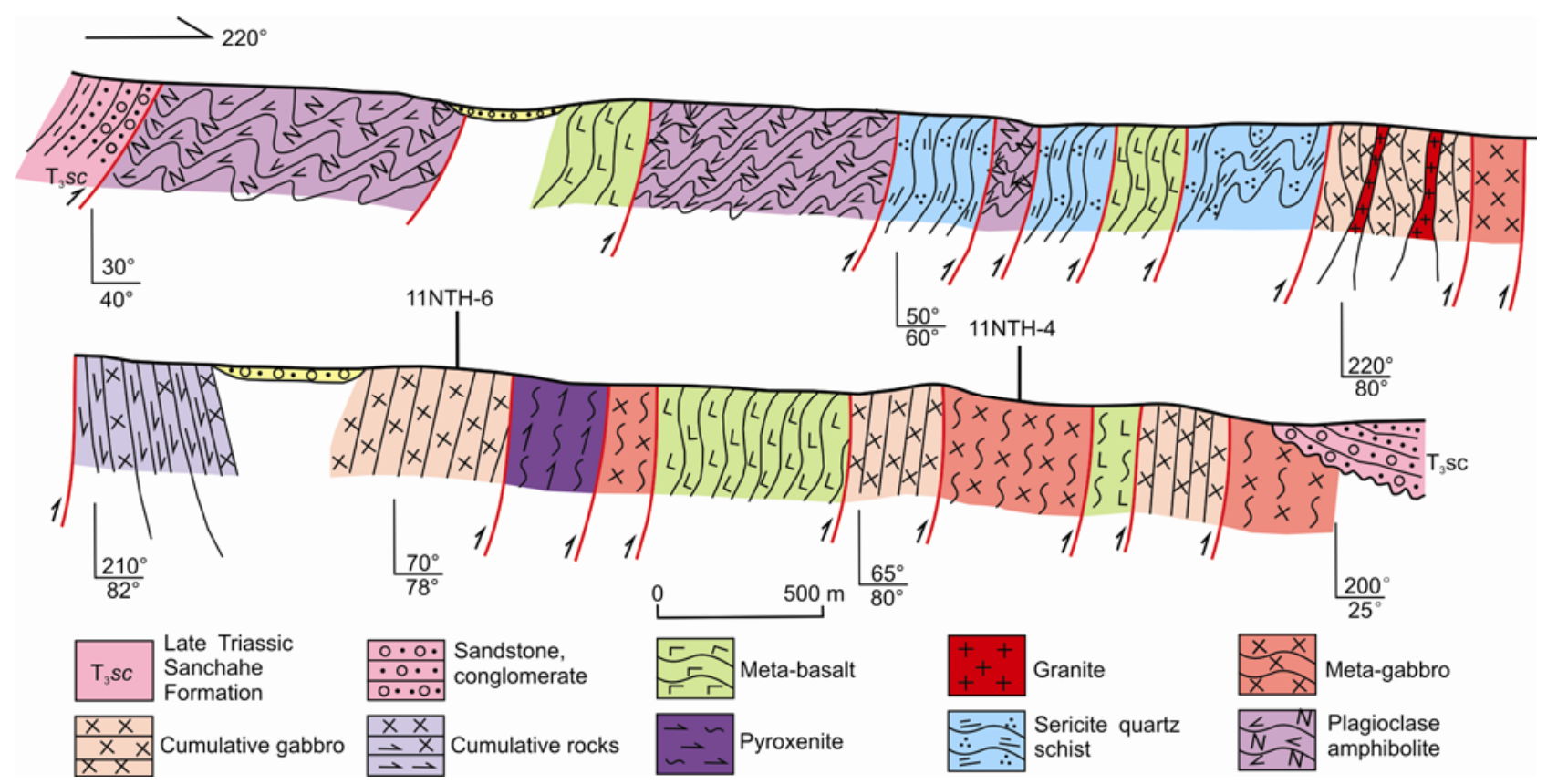

Figure 2 The section of the Nantinghe ophiolite in the Changning-Menglian suture zone. 

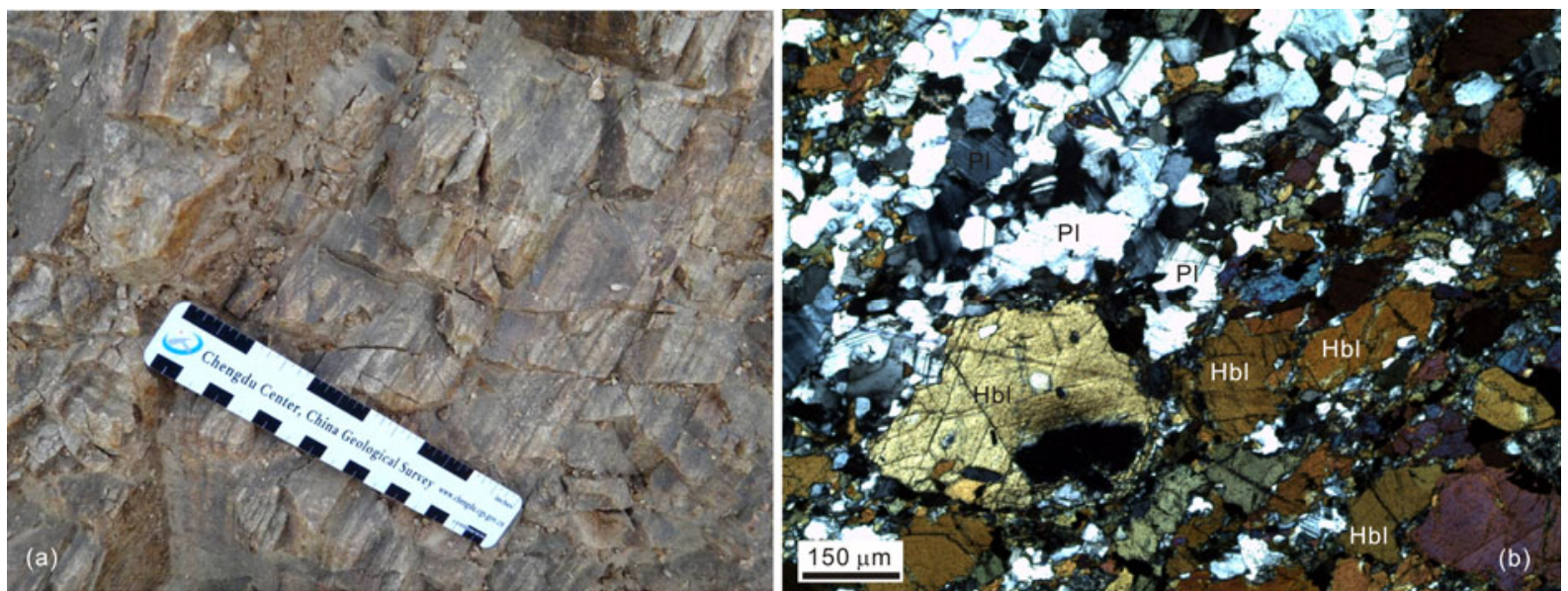

Figure 3 The photograph in the field (a) and Micro-texture characteristics of cumulative gabbro in the Nantinghe ophiolite (b). (b) Pl, Plagioclase; Hbl, Hornblende.

Resources, Faculty of Earth Sciences, China University of Geosciences (Wuhan). Off-line selection and integration of background and analyte signals, and time-drift correction and quantitative calibration for trace element analyses and $\mathrm{U}-\mathrm{Pb}$ dating were performed by ICPMSDataCal [11,12]. Detailed operating conditions for the laser ablation system and the ICP-MS instrument and data reduction are the same as description as Liu et al. [11,12]. Concordia diagrams and weighted mean calculations were made using Isoplot/Ex ver3 [13]. Results are presented in Table 1.

The major and trace elements are analyzed at State Key Laboratory of Isotope Geochemistry (Guangzhou). Major ele-

Table 1 LA-ICPMS U-Pb zircon data of the Nantinghe ophiolite in the Changning-Menglian suture zone (11NTH-4, 11NTH-6)

\begin{tabular}{|c|c|c|c|c|c|c|c|c|c|c|c|c|c|c|c|c|}
\hline \multirow{2}{*}{ Plot } & \multirow{2}{*}{$\begin{array}{c}\mathrm{Pb} \\
(\mathrm{ppm})\end{array}$} & \multirow{2}{*}{$\begin{array}{c}\text { Th } \\
(\mathrm{ppm})\end{array}$} & \multirow{2}{*}{$\begin{array}{c}\mathrm{U} \\
(\mathrm{ppm})\end{array}$} & \multirow[b]{2}{*}{$\mathrm{Th} / \mathrm{U}$} & \multicolumn{2}{|c|}{${ }^{207} \mathrm{~Pb} /{ }^{206} \mathrm{~Pb}$} & \multicolumn{2}{|c|}{${ }^{207} \mathrm{~Pb} /{ }^{235} \mathrm{U}$} & \multicolumn{2}{|c|}{${ }^{206} \mathrm{~Pb} /{ }^{238} \mathrm{U}$} & \multicolumn{2}{|c|}{${ }^{207} \mathrm{~Pb} /{ }^{206} \mathrm{~Pb}$} & \multicolumn{2}{|c|}{${ }^{207} \mathrm{~Pb} /{ }^{235} \mathrm{U}$} & \multicolumn{2}{|c|}{${ }^{206} \mathrm{~Pb} /{ }^{238} \mathrm{U}$} \\
\hline & & & & & Ratio & $1 \sigma$ & Ratio & $1 \sigma$ & Ratio & $1 \sigma$ & $\begin{array}{l}\text { Age } \\
(\mathrm{Ma}) \\
\end{array}$ & $1 \sigma$ & $\begin{array}{l}\text { Age } \\
(\mathrm{Ma})\end{array}$ & $1 \sigma$ & $\begin{array}{l}\text { Age } \\
\text { (Ma) }\end{array}$ & $1 \sigma$ \\
\hline \multicolumn{17}{|c|}{$11 \mathrm{NTH}-4$} \\
\hline 1 & 13.8 & 86.8 & 146 & 0.59 & 0.057 & 0.003 & 0.544 & 0.029 & 0.071 & 0.0012 & 476 & 126 & 441 & 19 & 444 & 7 \\
\hline 2 & 5.46 & 28.8 & 61.9 & 0.46 & 0.079 & 0.006 & 0.711 & 0.046 & 0.069 & 0.0016 & 1162 & 150 & 545 & 27 & 431 & 9 \\
\hline 3 & 10.7 & 63.4 & 120 & 0.53 & 0.065 & 0.004 & 0.616 & 0.035 & 0.070 & 0.0014 & 787 & 126 & 488 & 22 & 434 & 9 \\
\hline 4 & 9.08 & 46.3 & 101 & 0.46 & 0.069 & 0.005 & 0.663 & 0.043 & 0.072 & 0.0014 & 898 & 138 & 516 & 26 & 446 & 8 \\
\hline 5 & 6.42 & 33.7 & 74.7 & 0.45 & 0.066 & 0.005 & 0.631 & 0.045 & 0.070 & 0.0016 & 809 & 147 & 497 & 28 & 437 & 9 \\
\hline 6 & 7.61 & 36.0 & 89.5 & 0.40 & 0.066 & 0.006 & 0.628 & 0.050 & 0.070 & 0.0012 & 794 & 176 & 495 & 31 & 436 & 7 \\
\hline 7 & 2.72 & 0.17 & 46.3 & 0.01 & 0.113 & 0.009 & 0.752 & 0.047 & 0.054 & 0.0017 & 1844 & 151 & 569 & 27 & 338 & 10 \\
\hline 8 & 4.10 & 0.42 & 73.3 & 0.01 & 0.093 & 0.007 & 0.620 & 0.043 & 0.051 & 0.0013 & 1480 & 105 & 490 & 27 & 318 & 8 \\
\hline 9 & 15.5 & 92.2 & 177 & 0.52 & 0.058 & 0.003 & 0.545 & 0.029 & 0.069 & 0.0011 & 517 & 117 & 442 & 19 & 432 & 7 \\
\hline 10 & 12.4 & 68.3 & 141 & 0.49 & 0.059 & 0.004 & 0.565 & 0.032 & 0.071 & 0.0012 & 572 & 135 & 455 & 21 & 440 & 7 \\
\hline 11 & 12.3 & 85.4 & 138 & 0.62 & 0.061 & 0.004 & 0.572 & 0.035 & 0.070 & 0.0014 & 639 & 138 & 459 & 23 & 436 & 8 \\
\hline 12 & 7.64 & 37.4 & 89.2 & 0.42 & 0.058 & 0.004 & 0.550 & 0.036 & 0.071 & 0.0015 & 524 & 186 & 445 & 24 & 442 & 9 \\
\hline 13 & 5.57 & 0.85 & 97.1 & 0.01 & 0.080 & 0.006 & 0.530 & 0.036 & 0.051 & 0.0012 & 1198 & 152 & 432 & 24 & 320 & 7 \\
\hline 14 & 16.0 & 4.18 & 275 & 0.02 & 0.056 & 0.003 & 0.412 & 0.024 & 0.054 & 0.0009 & 454 & 131 & 351 & 17 & 339 & 6 \\
\hline 15 & 9.14 & 44.9 & 106 & 0.42 & 0.066 & 0.004 & 0.646 & 0.039 & 0.072 & 0.0015 & 1200 & 135 & 506 & 24 & 446 & 9 \\
\hline 16 & 10.0 & 68.4 & 112 & 0.61 & 0.057 & 0.004 & 0.540 & 0.035 & 0.070 & 0.0013 & 494 & 146 & 438 & 23 & 434 & 8 \\
\hline 17 & 4.96 & 38.0 & 52.9 & 0.72 & 0.084 & 0.007 & 0.812 & 0.065 & 0.073 & 0.0018 & 1300 & 159 & 604 & 36 & 451 & 11 \\
\hline 18 & 9.34 & 51.2 & 103 & 0.50 & 0.064 & 0.004 & 0.629 & 0.036 & 0.073 & 0.0014 & 752 & 130 & 496 & 22 & 452 & 8 \\
\hline 19 & 5.61 & 34.4 & 65.1 & 0.53 & 0.067 & 0.005 & 0.628 & 0.039 & 0.069 & 0.0016 & 850 & 148 & 495 & 24 & 429 & 10 \\
\hline 20 & 4.65 & 21.6 & 55.1 & 0.39 & 0.076 & 0.005 & 0.703 & 0.042 & 0.070 & 0.0016 & 1083 & 127 & 541 & 25 & 437 & 10 \\
\hline
\end{tabular}


(Continued)

\begin{tabular}{|c|c|c|c|c|c|c|c|c|c|c|c|c|c|c|c|c|}
\hline \multirow{2}{*}{ Plot } & \multirow{2}{*}{$\begin{array}{c}\mathrm{Pb} \\
(\mathrm{ppm})\end{array}$} & \multirow{2}{*}{$\begin{array}{c}\mathrm{Th} \\
(\mathrm{ppm})\end{array}$} & \multirow{2}{*}{$\begin{array}{c}\mathrm{U} \\
(\mathrm{ppm})\end{array}$} & \multirow{2}{*}{$\mathrm{Th} / \mathrm{U}$} & \multicolumn{2}{|c|}{${ }^{207} \mathrm{~Pb} /{ }^{206} \mathrm{~Pb}$} & \multicolumn{2}{|c|}{${ }^{207} \mathrm{~Pb} /{ }^{235} \mathrm{U}$} & \multicolumn{2}{|c|}{${ }^{206} \mathrm{~Pb} /{ }^{238} \mathrm{U}$} & \multicolumn{2}{|c|}{${ }^{207} \mathrm{~Pb} /{ }^{206} \mathrm{~Pb}$} & \multicolumn{2}{|c|}{${ }^{207} \mathrm{~Pb} /{ }^{235} \mathrm{U}$} & \multicolumn{2}{|c|}{${ }^{206} \mathrm{~Pb} /{ }^{238} \mathrm{U}$} \\
\hline & & & & & Ratio & $1 \sigma$ & Ratio & $1 \sigma$ & Ratio & $1 \sigma$ & Ratio & $1 \sigma$ & Ratio & $1 \sigma$ & Ratio & $1 \sigma$ \\
\hline \multicolumn{17}{|c|}{$11 \mathrm{NTH}-6$} \\
\hline 1 & 6.80 & 59.7 & 73.7 & 0.81 & 0.083 & 0.006 & 0.793 & 0.050 & 0.071 & 0.0016 & 1276 & 130 & 593 & 28 & 440 & 10 \\
\hline 2 & 3.08 & 12.1 & 35.0 & 0.35 & 0.127 & 0.010 & 1.145 & 0.076 & 0.072 & 0.0024 & 2050 & 141 & 775 & 36 & 449 & 14 \\
\hline 3 & 7.99 & 44.2 & 84.3 & 0.52 & 0.079 & 0.005 & 0.825 & 0.058 & 0.077 & 0.0017 & 1161 & 136 & 611 & 33 & 478 & 10 \\
\hline 4 & 11.1 & 69.0 & 114 & 0.61 & 0.080 & 0.005 & 0.830 & 0.050 & 0.077 & 0.0014 & 1194 & 129 & 613 & 28 & 477 & 8 \\
\hline 5 & 15.1 & 104 & 156 & 0.67 & 0.058 & 0.003 & 0.609 & 0.033 & 0.077 & 0.0013 & 520 & 126 & 483 & 21 & 475 & 8 \\
\hline 6 & 14.0 & 116 & 150 & 0.77 & 0.058 & 0.004 & 0.569 & 0.039 & 0.071 & 0.0014 & 539 & 149 & 457 & 25 & 444 & 8 \\
\hline 7 & 4.17 & 26.3 & 48.4 & 0.54 & 0.118 & 0.012 & 1.031 & 0.064 & 0.071 & 0.0023 & 1920 & 189 & 719 & 32 & 444 & 14 \\
\hline 8 & 9.39 & 81.0 & 102 & 0.80 & 0.066 & 0.004 & 0.602 & 0.040 & 0.071 & 0.0022 & 794 & 139 & 478 & 25 & 441 & 13 \\
\hline 9 & 19.4 & 155 & 196 & 0.79 & 0.064 & 0.004 & 0.655 & 0.036 & 0.076 & 0.0012 & 744 & 124 & 511 & 22 & 471 & 7 \\
\hline 10 & 18.9 & 180 & 184 & 0.98 & 0.062 & 0.003 & 0.646 & 0.033 & 0.076 & 0.0012 & 680 & 113 & 506 & 20 & 473 & 7 \\
\hline 11 & 19.5 & 187 & 192 & 0.98 & 0.067 & 0.003 & 0.676 & 0.032 & 0.073 & 0.0010 & 848 & 102 & 525 & 19 & 455 & 6 \\
\hline 12 & 23.5 & 262 & 237 & 1.11 & 0.055 & 0.003 & 0.530 & 0.027 & 0.070 & 0.0010 & 433 & 126 & 432 & 18 & 438 & 6 \\
\hline 13 & 19.8 & 206 & 197 & 1.04 & 0.060 & 0.003 & 0.576 & 0.032 & 0.071 & 0.0011 & 587 & 122 & 462 & 21 & 441 & 6 \\
\hline 14 & 10.3 & 65.2 & 105 & 0.62 & 0.059 & 0.004 & 0.605 & 0.041 & 0.076 & 0.0014 & 583 & 146 & 480 & 26 & 473 & 9 \\
\hline 15 & 17.7 & 173 & 165 & 1.05 & 0.063 & 0.004 & 0.663 & 0.036 & 0.076 & 0.0012 & 720 & 122 & 516 & 22 & 471 & 7 \\
\hline 16 & 8.37 & 52.1 & 87.2 & 0.60 & 0.079 & 0.006 & 0.787 & 0.052 & 0.076 & 0.0018 & 1159 & 144 & 590 & 29 & 475 & 11 \\
\hline 17 & 10.9 & 61.7 & 114 & 0.54 & 0.069 & 0.006 & 0.700 & 0.053 & 0.076 & 0.0019 & 906 & 167 & 539 & 32 & 471 & 11 \\
\hline 18 & 14.6 & 89.4 & 149 & 0.60 & 0.066 & 0.004 & 0.671 & 0.039 & 0.076 & 0.0014 & 798 & 130 & 521 & 23 & 471 & 8 \\
\hline 19 & 10.0 & 77.3 & 95.7 & 0.81 & 0.064 & 0.005 & 0.645 & 0.044 & 0.076 & 0.0017 & 750 & 156 & 505 & 27 & 475 & 10 \\
\hline 20 & 10.3 & 81.6 & 108 & 0.75 & 0.059 & 0.004 & 0.554 & 0.034 & 0.071 & 0.0013 & 561 & 143 & 447 & 22 & 440 & 8 \\
\hline
\end{tabular}

ments were determined using the standard X-ray fluorescence (XRF, Rigaku RIX 2100) method, Analytical precision is better than $4 \%$. Trace elements were analyzed by inductively coupled plasma mass spectrometry (ICP-MS), using a Perkin-Elmer Sciex ELAN 6000 instrument, analytical precision for most elements is better than $2 \%-5 \%$. Analytical procedures are the same as those described by Chen et al. [14]. Major and trace elements results are listed in Table 2.

\section{Analytical results}

\subsection{Zircon geochronology}

The zircon grains from a sample of gabbro (11NTH-4) demonstrated the grain size mostly between $60-100 \mu \mathrm{m}$ in the CL images (Figure 4(a)). Most of the zircons show regular oscillatory magmatic zoning, Their Th/U ratios $(>0.3)$ are higher than those of metamorphic zircons that generally show lower $\mathrm{Th} / \mathrm{U}$ ratios $(<0.1)$, but consistent with those of the magmatic zircon $[15,16]$. Twenty $\mathrm{U}-\mathrm{Pb}$ analyses of zircons show two groups of curves, that is a discordant (4 spots) and the other concordant (16 spots). The ${ }^{206} \mathrm{~Pb} /{ }^{238} \mathrm{U}$ ages of the former, is ranging from 338 to 318 Ma giving by four analyzed spots $(7,8,13,14)$, and showing discordant curves, which is clearly different from the other 16 analyzed spots give yielding identical and concordant ${ }^{206} \mathrm{~Pb} /{ }^{238} \mathrm{U}$ ages, with highly euhedral and clear oscillatory growth zonation. However, based on the CL images, the six zircons of latter having concordant curves $(01,05,09,11,15$ and 23) show wide growth zoning with a narrow uncoordinated growth outside, which is too narrow to be dated and is likely of metamorphic origin. The 16 analyzed spots have high Th (52.9-177 ppm) and U (38.0-92.2 ppm) contents and a positive relationship, and high $\mathrm{Th} / \mathrm{U}$ ratios (0.39-0.72), suggesting a magmatic origin [16]. They give a concordant ${ }^{206} \mathrm{~Pb} /{ }^{238} \mathrm{U}$ ages ranging from 429 to $452 \mathrm{Ma}$, which correspond to a single age population with a weighted mean ${ }^{206} \mathrm{~Pb} /{ }^{238} \mathrm{U}$ age of $439.0 \pm 2.4 \mathrm{Ma}(2 \sigma, \mathrm{MSWD}=0.64, n=16)$ (Figure 5(a)). According to the gabbro petrology, and Th/U ratios and CL image of zircons, the ${ }^{206} \mathrm{~Pb} /{ }^{238} \mathrm{U}$ ages is interpreted to be the crystallization age of the gabbro.

Comparing with the zircon grains of gabbro sample (11NTH-4), those from the cumulative gabbro sample (11NTH-6) are distinct larger (100-200 $\mu \mathrm{m})$, with 2-3 of length/width ratios. Based on the CL images, the zircons of cumulative gabbro sample (11NTH-6) can be divided into two groups: the group I have an internal magmatic oscillatory zoning, with an growth side, which is too narrow to be 
Table 2 Major (\%) and trace elements (ppm) data of the cumulative gabbro and gabbro of the Nantinghe ophiolite in the Changning-Menglian suture zone

\begin{tabular}{|c|c|c|c|c|c|c|}
\hline \multirow{2}{*}{ Major \& trace elements } & \multirow{2}{*}{$\begin{array}{c}\text { Gabbro } \\
11 \mathrm{NTH}-4 \\
\end{array}$} & \multicolumn{5}{|c|}{ Cumulative gabbro } \\
\hline & & 11 NTH-6 & 11 NTH-7 & $11 \mathrm{NTH}-8$ & 11 NTH-9 & $11 \mathrm{NTH}-10$ \\
\hline $\mathrm{SiO}_{2}$ & 46.46 & 49.40 & 52.11 & 51.71 & 50.13 & 50.19 \\
\hline $\mathrm{TiO}_{2}$ & 1.14 & 0.99 & 0.99 & 1.01 & 1.05 & 0.96 \\
\hline $\mathrm{Al}_{2} \mathrm{O}_{3}$ & 19.26 & 18.88 & 18.80 & 18.59 & 19.04 & 17.88 \\
\hline $\mathrm{Fe}_{2} \mathrm{O}_{3} \mathrm{~T}$ & 11.86 & 10.92 & 9.70 & 9.98 & 10.84 & 10.50 \\
\hline $\mathrm{MnO}$ & 0.19 & 0.17 & 0.19 & 0.20 & 0.17 & 0.16 \\
\hline $\mathrm{MgO}$ & 5.80 & 5.03 & 4.38 & 4.47 & 5.08 & 6.11 \\
\hline $\mathrm{CaO}$ & 10.26 & 8.84 & 7.99 & 8.51 & 8.68 & 9.41 \\
\hline $\mathrm{Na}_{2} \mathrm{O}$ & 3.24 & 3.68 & 3.87 & 3.73 & 3.54 & 3.25 \\
\hline $\mathrm{K}_{2} \mathrm{O}$ & 0.48 & 0.75 & 0.70 & 0.55 & 0.54 & 0.57 \\
\hline $\mathrm{P}_{2} \mathrm{O}_{5}$ & 0.23 & 0.20 & 0.20 & 0.21 & 0.18 & 0.14 \\
\hline LOI & 0.98 & 1.05 & 0.96 & 0.93 & 0.66 & 0.73 \\
\hline Total & 99.90 & 99.91 & 99.89 & 99.89 & 99.91 & 99.90 \\
\hline $\mathrm{Sc}$ & 40.5 & 22.9 & 23.6 & 24.8 & 26.0 & 30.7 \\
\hline $\mathrm{V}$ & 281 & 280 & 252 & 262 & 255 & 298 \\
\hline $\mathrm{Cr}$ & 129 & 59.8 & 47.6 & 45.5 & 61.7 & 113 \\
\hline Co & 41.4 & 32.0 & 25.4 & 26.2 & 30.9 & 31.2 \\
\hline $\mathrm{Ni}$ & 67.0 & 36.1 & 22.8 & 21.8 & 36.5 & 67.4 \\
\hline $\mathrm{Rb}$ & 3.80 & 6.53 & 7.08 & 3.95 & 3.63 & 3.39 \\
\hline $\mathrm{Sr}$ & 201 & 793 & 748 & 796 & 677 & 796 \\
\hline $\mathrm{Y}$ & 34.5 & 11.5 & 15.2 & 15.8 & 18.5 & 12.2 \\
\hline $\mathrm{Zr}$ & 137 & 22.3 & 16.4 & 19.4 & 35.7 & 20.5 \\
\hline $\mathrm{Nb}$ & 6.00 & 1.83 & 2.47 & 2.61 & 3.09 & 1.36 \\
\hline Cs & 0.23 & 0.39 & 0.29 & 0.18 & 0.18 & 0.33 \\
\hline $\mathrm{Ba}$ & 25.6 & 269 & 298 & 275 & 264 & 190 \\
\hline $\mathrm{Hf}$ & 3.36 & 0.77 & 0.64 & 0.73 & 1.05 & 0.73 \\
\hline $\mathrm{Ta}$ & 0.40 & 0.08 & 0.10 & 0.11 & 0.16 & 0.07 \\
\hline $\mathrm{Pb}$ & 2.05 & 4.30 & 5.24 & 6.67 & 5.03 & 4.45 \\
\hline Th & 0.48 & 0.14 & 0.25 & 0.25 & 0.26 & 0.28 \\
\hline $\mathrm{U}$ & 0.16 & 0.03 & 0.07 & 0.07 & 0.06 & 0.05 \\
\hline $\mathrm{La}$ & 6.17 & 11.9 & 14.2 & 14.7 & 14.1 & 10.7 \\
\hline $\mathrm{Ce}$ & 16.8 & 27.6 & 32.4 & 33.7 & 32.7 & 24.8 \\
\hline $\operatorname{Pr}$ & 2.80 & 3.92 & 4.37 & 4.62 & 4.62 & 3.54 \\
\hline $\mathrm{Nd}$ & 14.3 & 17.4 & 19.7 & 20.9 & 20.9 & 16.0 \\
\hline $\mathrm{Sm}$ & 4.36 & 3.66 & 4.08 & 4.25 & 4.50 & 3.48 \\
\hline $\mathrm{Eu}$ & 1.49 & 1.20 & 1.33 & 1.41 & 1.37 & 1.11 \\
\hline $\mathrm{Gd}$ & 5.29 & 3.18 & 3.64 & 3.83 & 4.18 & 3.03 \\
\hline $\mathrm{Tb}$ & 0.95 & 0.42 & 0.51 & 0.55 & 0.62 & 0.43 \\
\hline Dy & 6.24 & 2.31 & 2.96 & 3.01 & 3.63 & 2.40 \\
\hline Ho & 1.36 & 0.46 & 0.59 & 0.62 & 0.76 & 0.47 \\
\hline Er & 3.73 & 1.19 & 1.62 & 1.66 & 1.99 & 1.25 \\
\hline $\mathrm{Tm}$ & 0.55 & 0.17 & 0.23 & 0.24 & 0.27 & 0.18 \\
\hline $\mathrm{Yb}$ & 3.39 & 1.05 & 1.50 & 1.55 & 1.81 & 1.20 \\
\hline $\mathrm{Lu}$ & 0.53 & 0.16 & 0.24 & 0.24 & 0.27 & 0.18 \\
\hline
\end{tabular}



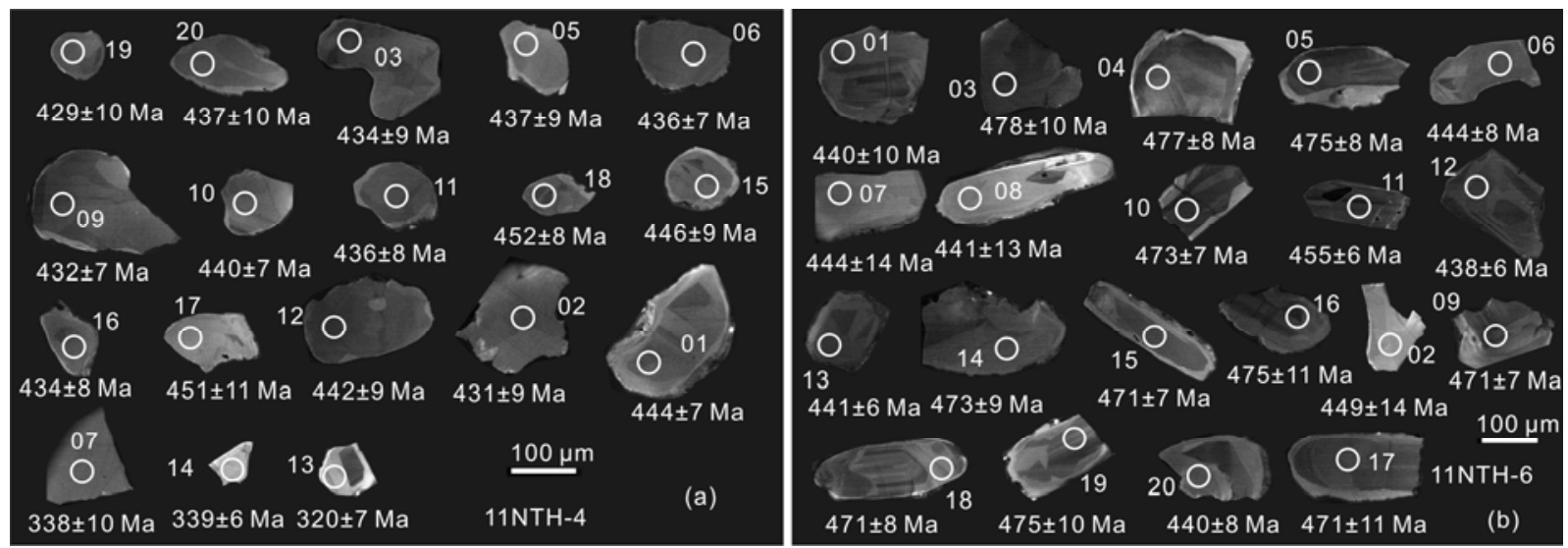

Figure 4 The CL images of zircons of the gabbro (a) and cumulative gabbro (b) in the Nantinghe ophiolite.
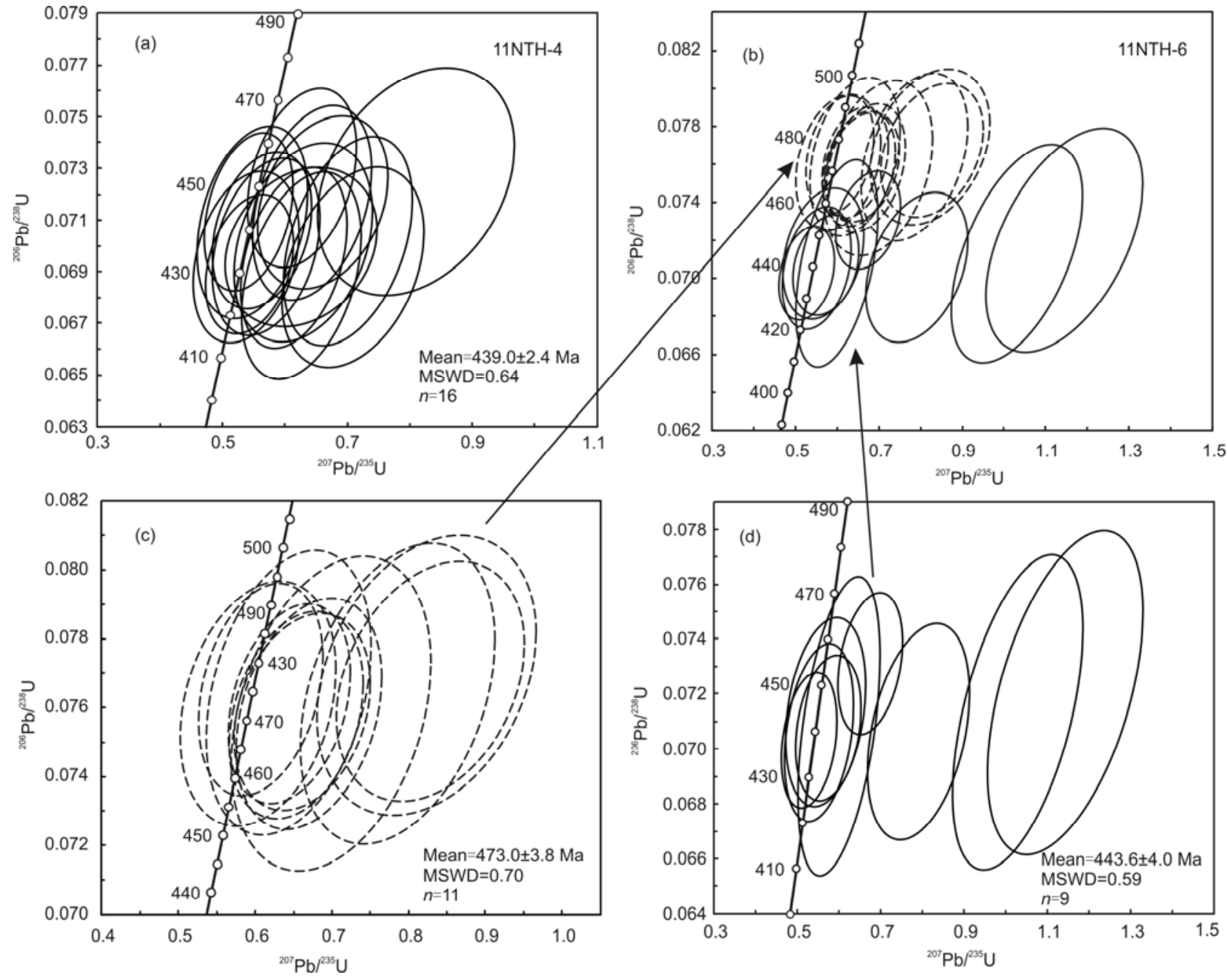

Figure 5 U-Pb concordia diagram of zircons from gabbro (a) and cumulative gabbro (b)-(d) in the Nantinghe ophiolite.

dated and likely of metamorphic origin; the group II have not, with variable magmatic oscillatory zoning (Figure 4(b)). The eleven analyzed spots of group I are characterized by moderate U (84.2-196 ppm) and Th (44.2-180 ppm) con- tents (Figure 5(b)), with relatively high $\mathrm{Th} / \mathrm{U}$ ratios (0.52-1.05), consistent with a magmatic origin [16]. They give apparent ${ }^{206} \mathrm{~Pb} /{ }^{238} \mathrm{U}$ ages ranging from 471 to $478 \mathrm{Ma}$, corresponding to a single age population with a weighted 
mean ${ }^{206} \mathrm{~Pb} /{ }^{238} \mathrm{U}$ age of $473.0 \pm 3.8$ Ma $(2 \sigma, \mathrm{MSWD}=0.7$, $n=11$ ) (Figure 5(c)). The nine analyzed spots for the group II contain moderate U (35.0-237 ppm) and Th (12.1-262 $\mathrm{ppm}$ ) contents, with $\mathrm{Th} / \mathrm{U}$ ratios from 0.35 to 1.11 , consistent with a magmatic origin [16]. They yield ${ }^{206} \mathrm{~Pb} /{ }^{238} \mathrm{U}$ ages ranging from 438 to $455 \mathrm{Ma}$, corresponding to a single age population with a weighted mean ${ }^{206} \mathrm{~Pb} /{ }^{238} \mathrm{U}$ age of 443.6 $\pm 4.0 \mathrm{Ma}(2 \sigma, \mathrm{MSWD}=0.59, n=9)$ (Figure 5(d)).

\subsection{Geochemical characteristics}

The Nantinghe gabbros and cumulative gabbros have low $\mathrm{SiO}_{2}(46.46 \%-52.11 \%)$ and $\mathrm{K}_{2} \mathrm{O}(0.48 \%-0.75 \%)$, moderate $\mathrm{MgO}(4.38 \%-6.11 \%), \mathrm{TiO}_{2}(0.96 \%-1.14 \%)$, and high $\mathrm{Na}_{2} \mathrm{O}$ (3.24\%-3.87\%) contents. Their $\mathrm{TiO}_{2}, \mathrm{Fe}_{2} \mathrm{O}_{3} \mathrm{~T}, \mathrm{Al}_{2} \mathrm{O}_{3}, \mathrm{MgO}$, $\mathrm{CaO}$ and $\mathrm{P}_{2} \mathrm{O}_{5}$ contents decrease with increasing $\mathrm{SiO}_{2}$ contents (not shown), indicating a genetic relationship and a certain fractional crystallization for those rocks. Considering slight alteration of the rocks in this study, the immobile elements (such as $\mathrm{Zr}, \mathrm{Ti}, \mathrm{Nb}, \mathrm{Y}$ ) were selected to discuss the rocks classification and tectonic discrimination, in which they are plot in the field of basalt (Figure 6(a)).

The samples in this study have high rare earth elements
(REE) contents (67.9-91.6 ppm). Both of the chondritenormalized REE patterns and the primitive mantle-normalized trace element spidergram show two types. The first type is depleted in light REE (LREE), similar to the patterns of not only the normal mid-ocean-ridge basalts (N-MORB) (Figure 6(b)) but also cumulative gabbros from Taoxinghu and Guoganjianianshan areas $[17,18]$. The second type is enriched LREE and depleted heavy REE (HREE), similar to enriched MORB (E-MORB). It has very low concentrations of high field strength elements (HFSE) such as $\mathrm{Nb}, \mathrm{Ta}, \mathrm{Zr}$, $\mathrm{Hf}$ and $\mathrm{Ti}$, resulting in strongly negative anomalies of $\mathrm{Zr}$, Hf and Ti (Figure 6(c)). This suggests the influence of subduction-zone fluid components on its mantle source, similar to the suprasubduction-zone (SSZ) type of ophiolites.

\section{Discussion}

\subsection{The Early Paleozoic oceanic crust recognition in the Nantinghe area from the Changning-Menglian suture zone}

The zircons internal structure of samples in this study, display the clear patch like shapes, variational width of oscillatory
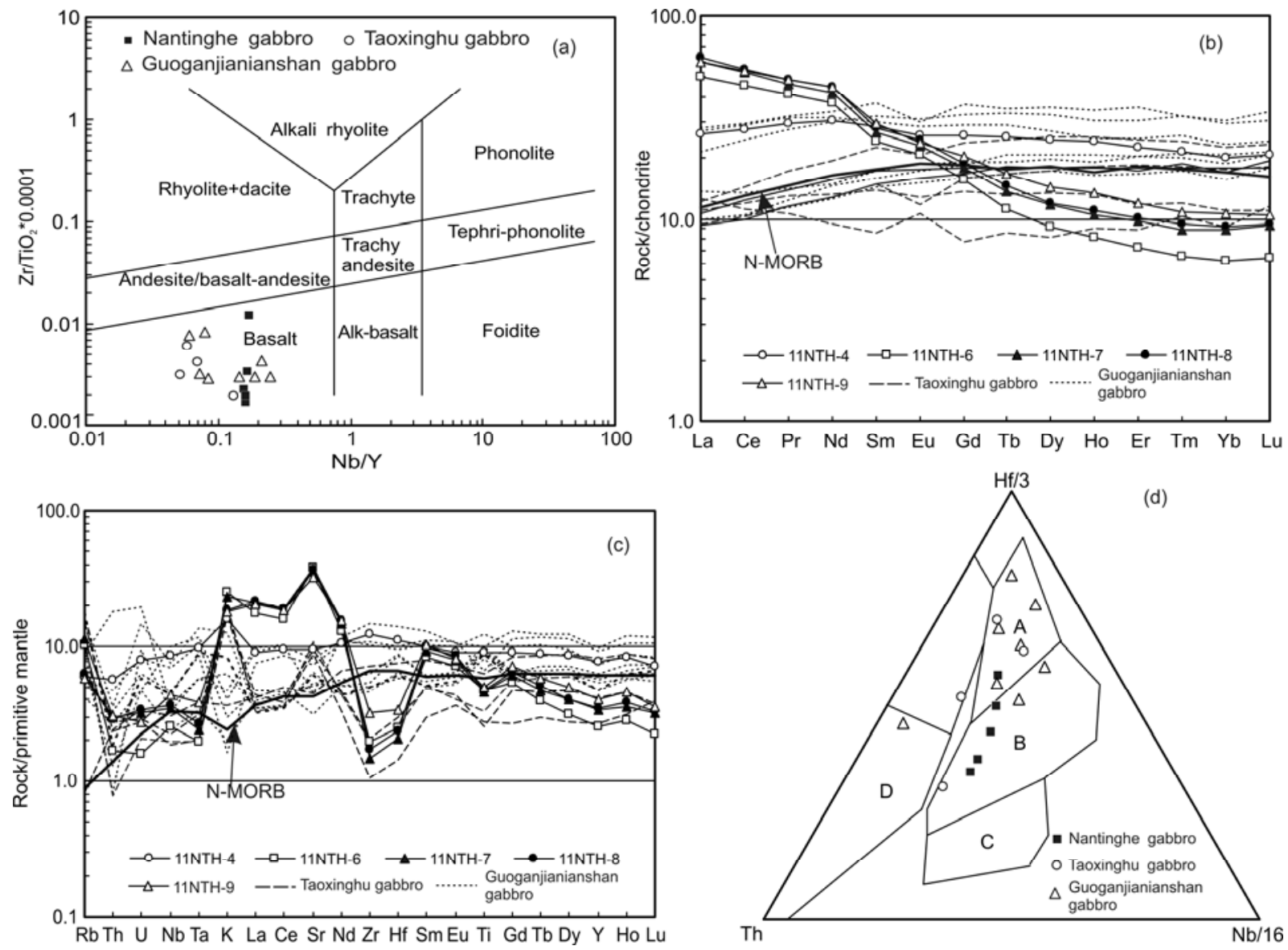

Figure 6 The diagrams of the $\mathrm{Nb} / \mathrm{Y}$ vs. $\mathrm{Zr} / \mathrm{TiO}_{2}$ (a), chondrite-normalized REE patterns (b), primitive mantle normalized trace element spider diagram (c), and teconic environments diagrams of gabbro and cumulative gabbro in the Nantinghe ophiolite (d). (d) A, N-MORB; B, E-MORB; C, Intraplate alkaline basalts; D, Island arc tholeiite. 
zoning, coupled with high $\mathrm{Th} / \mathrm{U}$ ratios $(0.35-1.11)$, consistent with a mafic magmatic origin and unaffected by contamination from the continental crust. The sixteen analyzed spots from the gabbro sample (11NTH-4) have concordant ${ }^{206} \mathrm{~Pb} /{ }^{238} \mathrm{U}$ ages ranging from 429 to $452 \mathrm{Ma}$. They form a discrete population with a weighted mean ${ }^{206} \mathrm{~Pb} /{ }^{238} \mathrm{U}$ age of $439 \pm 2.4 \mathrm{Ma}$, considered to be the crystallization age of the meta-gabbro. The cumulative gabbros (11NTH-6) clearly have two group ages (Group I and II). The eleven analyzed spots of Group I have concordant ${ }^{206} \mathrm{~Pb} /{ }^{238} \mathrm{U}$ ages ranging from 471 to $478 \mathrm{Ma}$, and yield a weighted mean ${ }^{206} \mathrm{~Pb} /{ }^{238} \mathrm{U}$ age of $473.0 \pm 3.8 \mathrm{Ma}$, representing the early magmatic event. The nine analyzed spots for Group II give ${ }^{206} \mathrm{~Pb} /{ }^{238} \mathrm{U}$ ages ranging from 438 to $455 \mathrm{Ma}$, with a weighted mean ${ }^{206} \mathrm{~Pb} /{ }^{238} \mathrm{U}$ age of $443.6 \pm 4.0 \mathrm{Ma}$, which is taken to represents the late crystallization age of the cumulative gabbro. The age of Group II is identical to the age of gabbro within analytical errors.

More importantly, the two types of mafic rocks show contrasts in their trace element compositions. The first type exhibits the N-MORB-like REE distribution patterns, and the second type exhibits the E-MORB-like REE patterns, indicating that they may have formed in the mid-ocean ridge setting (Figure 6(d)). In particular, the second type is depleted in HFSE. This indicates the incorporation of subduction-zone fluid components into its mantle source, partly like island arc basalts (IAB). Taken together, a tectonic setting of backarc rift basin is indicated by coexisting MORBand IAB-like patterns of trace element distribution in mafic igneous rocks [19]. These geochronological and geochemical characteristics imply that there was likely to have an oceanic basin during 444-439 $\mathrm{Ma}$ in the Nantinghe area in the Changning-Menglian suture zone.

\subsection{The relationship between Changning-Menglian and Longmu Co-Shuanghu sutures}

The Changning-Menglian ophiolitic mélange was unconformably covered by Late Triassic Sanchahe Formation $\left(\mathrm{T}_{3} s c\right)$, middle Jurassic Huakaizuo Formation $\left(\mathrm{J}_{2} h\right)$. The middle Carboniferous volcanic rocks of Pingzhang Formation $\left(\mathrm{C}_{1} p z\right)$ were widely distributed in this belt, which was regarded as product of Changning-Menglian oceanic basin during flourishing period. However, the overlying carbonate sediments represent the shrinkage process of oceanic basin. Thus, the Changning-Menglian oceanic basin opened no later than Early Carboniferous [10]. Recently, numerous researchers discovered radiolarian chert from Early Devonian to Permian, such as Early Devonian Monograptus uniformis, Early Carboniferous Palaeory phosty.lus uar spina radiolarian in the deepwater flysch sedimentary chert from the west slope of the Meilixueshan, Late Carboniferous-Permian Albaillea sp. Pseudea Ibailla sp. in chert from the Zhayu-Bitu area [20]. In addition, the sedimentary geochemical characteristics, isotopic results, and radiolarian palaeoecology suggest that it was deep-sea oceanic basin sedimentary environment $[2,21,22]$. The Devonian, Carboniferous and Early Permian radiolarian cherts were also discovered at Manxin and Nongba areas from Menglian, Gengma and other regions. Moreover, Tongchangjie ophiolite to the north of this study area, and the layered amphibolite in the Menghuazhai area to the $12 \mathrm{~km}$ east of Shuangjiang country, formed at 385 [23,24] and $381 \mathrm{Ma}$ [10], respectively. Consequently, most researcher considered that the Changning-Menglian oceanic basin was opened during Devonian. Furthermore, the paleomagnetic data of the Sanjiang area in west Yunnan and east Tibet, combining with sedimentary record related to tectonic activity and paleontology geographical information, led the others to suggest that the oceanic basin expanded at middle Katian during Late Devonian (ca. $450 \mathrm{Ma}$ ) [25,26]. All of those evidences imply that there was an oceanic basin at the ChangningMenglian suture zone during Late Paleozoic. The fragments of oceanic crust in the Nantinghe area formed during 444$439 \mathrm{Ma}$ in this study, which combing with previous research results, allows us to consider that there are two episodes ophiolites in Early and Late Paleozoic at least.

Recent studying results suggested that the Early Palaeozoic oceanic basin had expanded in the Longmu CoShuanghu suture in the central Qiangtang of the Tibetan Plateau. The Palaeozoic ophiolite and ultrahigh-pressure metamorphic belt were found at Guoganjianianshan and Longmu Co-Shuanghu areas [27], respectively. The cumulative gabbros from the ophiolite, with SHRIMP zircon $\mathrm{U}-\mathrm{Pb}$ ages of $438 \pm 11 \mathrm{Ma}$ [28], 432 $\pm 7 \mathrm{Ma}$, and $461 \pm 7 \mathrm{Ma}$ [29], have been interpreted to be formed a tectonic settings similar to the N-MORB [18]. In addition, the rock assemblages of meta-ultramafic rocks, meta-cumulative gabbro, meta-gabbro (dolerite), meta-basalt and plagioclase granite occur in the Taoxinghu area in the Qiangtang region from the north Tibet, which show the sequence feature of a complete ophiolite suite. The meta-cumulative gabbro, which formed at $467 \pm 4 \mathrm{Ma}$, have weighted mean $\varepsilon_{\mathrm{Hf}}(t)$ of $5.0 \pm 0.3$, implying a depleted mantle sources. In addition, the geochemical characteristics of mafic rocks are similar to MORB [17]. These results suggest that there is an Early Palaeozoic ophiolite in Longmu Co-Shuanghu suture. In addition, Permian MORB-like ophiolite and Triassic radiolarian chert at Jiaomuri area in the central Qiangtang region, Late Devonian and Permian radiolarian chert at Caiduocha$\mathrm{ka}$ area to the east of the Shuanghu region [30-32], indicate that the ophiolites occurred in the Qiangtang region during the Late Palaeozoic. The above observations confirm that there are two episodes of ophiolites in the Longmu CoShuanghu belt during the Early and Late Palaeozoic at least. Because the tectonic emplacement of ophiolites is associated with transformation of either mid-ocean ridge or backarc rift basin to subduction zone, these mafic-ultramafic rocks would form in a tectonic setting of either the mid-ocean ridge or the backarc rift basin. 
Generally speaking, the mid-ocean ridge setting is suggested by the N-MORB-like patterns of trace element distribution, whereas the backarc rift basin is indicated by the coexisting MORB- and IAB-like patterns of trace element distribution [19]. Therefore, the Early Palaeozoic ophiolites for the Changning-Menglian suture zone and the Guoganjianianshan and Taoxinghu areas from the Qiangtang region are consistent with each other not only in the formation time but in the tectonic setting. They would have formed in the backarc rift basin and be emplaced due to the closure of backarc basin and arc-continent collision [19]. Consequently, the ophiolites of Guoganjianianshan and Taoxinghu in the Qiangtang region are likely to integrate with those ophiolites of Nantinghe in the Changning-Menglian zone from the Sanjiang area. Both of them probably represent the fragments of oceanic crust of the uniform Paleo-Tethys ocean: the Longmu Co-Shuanghu-Changning-Menglian Paleo-Tethys ocean, which existed from Ordovician to Permian at least. Combined with the formation age of the Late Palaeozoic magmatic zone in Lincang-Menghai, we suggest that the Changning-Menglian oceanic crust occurred in the Early Palaeozoic at least, which was subducted eastward, leading to the eruption of the Dazhonghe volcanic rocks during 421-418 Ma, closed at the end of the Permian, following arc-continental collision in the Triassic [33-36] and eventually being unconformably overlain during the Upper Triassic.

\section{Conclusions}

(1) The cumulative gabbro and gabbro from the Changning-Menglian zone gave the LA-ICPMS zircon U-Pb ages of 444-439 Ma, and show both MORB- and IAB-like geochemical characteristics. These indicate that Early Palaeozoic ophiolites occurred in the Changning-Menglian zone. The zircon U-Pb geochronology suggests that there is an oceanic basin during 444-439 Ma, probably a backarc rift basin.

(2) The Nantinghe ophiolite of the Changning-Menglian suture zone in the Sanjiang area can integrate with those ophiolites of Guoganjianianshan and Taoxinghu in the Qiangtang region, and both of them represent the fragments of oceanic crust of the uniform Paleo-Tethys and became emplaced due to the closure of backarc basin and arc-continent collision.

We thank Yongsheng Liu, Zhaochu Hu, Keqing Zong and Han Liu for their help with the lab work. We also thank two anonymous reviewers and editor for their constructive comments, which led to a better presentation of the final product. This work was supported by the National Basic Research Program of China (2009CB421003), the National Natural Science Foundation of China (41073033 and 40872055) and the Chinese Geological Survey Projects (1212011121259 and 1212011085119).

1 Liu B P. The Sedimentary Geology of Ancient Continental Margin (in Chinese). Wuhan: Chinese Geology University Press, 1992. 1211

2 Liu B P, Feng Q L, Fang N Q, et al. Tectonic evolution of PalaeoTethys Poly-island-ocean in Changning-Menglian and Lancangjiang belts, Southwestern Yunnan, China (in Chinese). Earth Sci-J Chin Univ Geosci, 1993, 18: 529-539

3 Zhong D L, Wu G Y. The discovery of ophiolite in southeastern Yunnan (in Chinese). Chin Sci Bull (Chin Ver), 1998, 43: 1365-1370

4 Cui C L, Zeng Y F, Duan L L, et al. Is there a Late Paleozoic great ocean in Changning-Menglian belt, Western Yunnan, China? (in Chinese ). Acta Sed Sin, 1999, 17: 176-182

5 Mo X X, Shen S Y, Zhu Q W. The Volcanic Rocks-the Ophiolite and Mineralization in Central and Southern Sanjiang Area (in Chinese). Beijing: Geological Publishing House, 1998. 1-128

6 Metcalfe I. Gondwanaland origin, dispersion, and accretion of East and Southeast Asian continental terranes. J South Am Earth Sci, 1994, 7: 333-347

7 Shen S Y, Feng Q L, Liu B P, et al. Study on ocean ridge, ocean island volcanic rocks of Changning-Menglian belt (in Chinese ). Geol Sci Technol Inf, 2002, 21: 13-17

8 Zhang Q, Zhou D J, Zhao D S, et al. Wilson cycle of the PaleoTethyan orogenic belt in Western Yunnan: Record of magmatism and discussion on mantle processes (in Chinese). Acta Petrol Sin, 1996, 12: 17-28

9 Yang W Q, Feng Q L, Duan X D. Late Devonian pillow basalt and bedded chert in Chmagning-Mengnma tectonic belt of southwestern Yunnan, China (in Chinese). Geol Bull Chin, 2007, 26: 739-747

10 Yunnan Institute of Geological Survey. The 1:250000 Regional Geological Survey Report of Fengqing City in the People's Republic of China (in Chinese). 2008

11 Liu Y, Hu Z, Gao S, et al. In situ analysis of major and trace elements of anhydrous minerals by LA-ICP-MS without applying an internal standard. Chem Geol, 2008, 257: 34-43

12 Liu Y, Gao S, Hu Z, et al. Continental and oceanic orust oecyclinginduced melt-peridotite interactions in the Trans-North China orogen: $\mathrm{U}-\mathrm{Pb}$ dating, $\mathrm{Hf}$ isotopes and trace elements in zircons from mantle xenoliths. J Petrol, 2010, 51: 537-571

13 Ludwig K R. User's manual for Isoplot 3.00: A Geochronological Toolkit for Microsoft Excel. Berkeley Geochronology Center Spec Pub, 2003, 41-70

14 Chen J, Xu J, Wang B, et al. Origin of Cenozoic alkaline potassic volcanic rocks at KonglongXiang, Lhasa terrane, Tibetan Plateau: Products of partial melting of a mafic lower-crustal source? Chem Geol, 2010, 273: 286-299

$15 \mathrm{Wu}$ Y B, Zheng Y F. The research of zircon mineralogy and constraints on interpretation of U-Pb ages (in Chinese). Chin Sci Bull, 2004, 49: 1589-1604

16 Hoskin P W O, Black L P. Metamorphic zircon formation by solid-state recrystallization of protolith igneous zircon. J Metamorph Geol, 2000, 18: 423-439

17 Zhai Q G, Wang J, Li C, et al. SHRIMP U-Pb dating and Hf isotopic analyses of Middle Ordovician meta-cumulative gabbro in central Qiangtang, northern Tibetan Plateau. Sci China Ser D-Earth Sci, 2010, 53: 657-664

18 Zhai Q G, Li C, Huang X P. The Paleo-Tethys ocean in Central Qiangtang, Tibet: Geochemical constraint of mafic rocks from Guoganjianian Mountain (in Chinese). Sci China Ser D-Earth Sci, 2007, 37: 866-872

19 Zheng Y F. Metamorphic chemical geodynamics in continental subduction zones. Chem Geol, 2012, doi: 10.1016/j.chemgeol.2012. 02.005 .

20 Li W C, Pan G T, Hou Z Q, et al. Metallogenic and Exploration Techniques of Multi-Island-Arc Basin-Collision Orogenic Belt in Southwest the "Three Rivers" (in Chinese). Beijing: Geological Publishing House, 2010. 1-107

21 Ding L, Zhong D L. Rare earth elements and cerium anomalies characteristics of chert of Paleo-Tethys in Changning-Menglian suture zone, Western Yunnan (in Chinese). Sci China Ser B, 1995, 25: 93-100 
22 Feng Q L, Cui X S, Liu B P. Discovery of late Permian bivalve-fauna from Laochang of Lancang, West Yunnan and its biogeographic characteristics (in Chinese). Earth Sci-J Chin Univ Geosci, 1992, 17: 512-520

23 Zhang Q, Li D Z. The characteristics of Yidun-type mafic-ultramafic rocks and their comparison with ophiolites (in Chinese). Acta Petrol Sin, 1990, 1990: 33-42

24 Cong B L, Wu G Y, Zhang Q, et al. Rocks tectonic evolution of Paleo-Tethyan tectonic belt in Western Yunnan, China (in Chinese). Sci China Ser B, 1993, 23: 1201-1207

25 Li P H, Gao R, Cui J W, et al. Paleomagnetic results from the three rivers region, SW China: Implications for the collisional and accretionary history (in Chinese ). Acta Geosci Sin, 2005, 26: 387-404

26 Li P H, Gao R, Cui J W, et al. The palaeomagnetic study of the collision and collage of major landmasses in the Nujiang-LancangjiangJinshajiang area in Western Yunnan and Eastern Xizang (in Chinese). Sed Geol Tethyan Geol, 2003, 23: 28-34

27 Li C, Zhai Q G, Dong Y S, et al. The discovery of eclogites in Central Qiangtang, Tibet Plateau and its significances (in Chinese). Chin Sci Bull, 2006, 51: 70-74

28 Li C, Dong Y S, Zhai Q G, et al. Discovery of Eopaleozoic ophiolite in the Qiangtang of Tibet Plateau: Evidence from SHRIMP U-Pb dating and its tectonic implications (in Chinese). Acta Petrol Sin, 2008, 24: 31-36

29 Wang L Q, Pan G T, Li C, et al. SHRIMP U-Pb zircon dating of
Eopaleozoic cumulative in Guoganjianian Mt. from central Qiangtang area of northern Tibet-Considering the evolvement of Proto-and Paleo-Tethys (in Chinese). Geol Bull Chin, 2008, 27: 2045-2056

30 Zhu T X, Zhang Q Y, Dong H, et al. Discovery of the Late Devonian and Late Permian radiolarian cherts in tectonic melanges in the Cedo Caka area,Shuanghu, northern Tibet, China (in Chinese). Geol Bull Chin, 2006, 25: 1413-1418

31 Zhai Q G, Li C, Cheng L R, et al. Geological features of Permian ophiolite in the Jiaomuri area, Qiangtang, Tibet, and its tectonic significance (in Chinese). Geol Bull Chin, 2004, 23: 1228-1230

32 Zhai Q G, Li C, Huang X P. Geochemistry of Permian basalt in the Jiaomuri area, Central Qiangtang, Tibet, China, and its tectonic significance (in Chinese ). Geol Bull Chin, 2006, 25: 1419-1427

33 Wang L Q, Li B, Wang B D, et al. 2012. Discovery of Late Silurian volcanic rocks in the Dazhonghe area, Yunxian-Jinggu magmatic arc belt, Western Yunnan, China and its geological significance (in Chinese ). Acta Petrol Sin, 2012, 28: 1517-1528

34 Zhu D C, Zhao Z D, Niu Y L, et al. The origin and pre-Cenozoic evolution of the Tibetan Plateau. Gondwana Res, 2012, (in press)

35 Pan G T, Wang L Q, Ding J, et al. The Geological Map of the Qinghai-Tibet Plateau and Adjacent Areas (1:1500000) (new) (in Chinese ). Beijing: Geological Publishing House, 2012

36 Pan G T, Wang L Q, Zhu D C. Thoughts on some important scientific problems in regional geological survey of the Qinghai-Tibet Plateau (in Chinese). Geol Bull Chin, 2004, 23: 12-19

Open Access This article is distributed under the terms of the Creative Commons Attribution License which permits any use, distribution, and reproduction in any medium, provided the original author(s) and source are credited. 